\title{
Global Scientific Outputs of Microsurgery Publications: A Bibliometric Approach About Yesterday, Today, and Tomorrow
}

\author{
Serkan Guler ${ }^{1}$, Ramadan Ozmanevra ${ }^{2}$, Sercan Çapkin ${ }^{1}$ \\ 1. Orthopaedics and Traumatology, Aksaray University, Faculty of Medicine, Aksaray, TUR 2. Orthopaedics and \\ Traumatology, University of Kyrenia, Dr. Suat Gunsel Hospital, Kyrenia, CYP
}

Corresponding author: Ramadan Ozmanevra, rozmanevra@gmail.com

\section{Abstract \\ Introduction}

Although there have been important developments in microsurgery in recent years, there is no current and comprehensive bibliometric study in the literature. In this study, we aimed to present a summary of the articles published on microsurgery between 1980 and 2019 with bibliometric analysis.

\section{Methods}

Articles published on microsurgery between 1980 and 2019 were withdrawn from the Web of Science database and analyzed by bibliometric methods. Citation analysis was performed to identify effective journals and articles. Keyword cluster and trends analyses were performed for a detailed analysis of the researched topics. Relationships between the article numbers of the countries and gross domestic product (GDP) and human development index (HDI) values were investigated using Spearman's correlation coefficient. A linear regression analysis was used to estimate the number of articles to be published in the future.

\section{Results}

A total of 3,537 publications related to microsurgery were found. Bibliometric analyses were performed in 2,063 articles (58.3\%) of these publications. The most active countries in publishing were the United States (504), Germany (286), and Italy (154), respectively. A statistically significant correlation was found between the article numbers and the GDP and HDI sizes of the countries $(r=0.758, p<0.001, r=0.659, p<0.001)$.

\section{Conclusion}

The economic size and development levels of the countries were an important factor in academic productivity in microsurgery. Undeveloped countries should be encouraged by performing multidisciplinary studies in this regard.

Review began $11 / 25 / 2020$ Review ended 12/15/2020 Published 12/21/2020

\section{() Copyright 2020}

Guler et al. This is an open access article distributed under the terms of the Creative Commons Attribution License CC-BY 4.0., which permits unrestricted use, distribution, and reproduction in any medium, provided the original author and source are credited.
Categories: Plastic Surgery, General Surgery, Orthopedics

Keywords: bibliometric analysis, microsurgery, citation analysis, web of science

\section{Introduction}

Microsurgery is a term used to describe the surgical techniques that require surgical microscopy and the necessary special instrumentation (microscopes, microstrums, and micro-sutures) to perform sensitive operations on small structures in our body [1]. It specializes in many clinical disciplines including microsurgical orthopedics, otorhinolaryngology, ophthalmology, neurosurgery, plastic surgery, transplantation surgery, oncology, gynecology, and urology [2]. There are highly efficient microsurgery applications in orthopedic surgery [3].

A bibliometric analysis involves analyzing scientific publications, such as published articles, books, congress abstracts, etc., using statistical methods. Although the number of scientific publications is increasing every day, access to medical literature is becoming easier. Therefore, it is difficult to search the literature for researchers who want to perform a new study on a subject. There is an increase in bibliometric studies in the field of health, in parallel with the significant increase in the number of publications in recent years. Researchers can easily access the summary information of thousands, sometimes tens of thousands, of articles published in a research area on a particular subject, through bibliometric studies. In addition, the most influential articles, active universities, authors, countries, and international collaborations can be determined in a short time. Important bibliometric studies have been conducted in many different disciplines in the field of health. Recently, some studies have been conducted in the field of anesthesia, neurosurgery, rhinoplasty, and general surgery [4-10]. 
Although there have been important developments in microsurgery in recent years, there is no current and comprehensive bibliometric study in the literature.

In this study, we aimed to present a summary of the articles published on microsurgery between 1980 and 2019 with bibliometric analysis. In addition, we aimed to reveal the most cited effective publications, active journals, countries, institutions, and authors; identify international collaborations; and discuss keyword analysis and trending research topics. We also aimed to determine the development of publications over the years and the factors affecting the productivity of the publication with correlation and regression analysis.

\section{Materials And Methods}

The literature review was performed using the Web of Science (WoS; Clarivate Analytics, Philadelphia, Pennsylvania) database (access date: May 10, 2020). All articles published on microsurgery were searched. All the publications with the keywords "microsurgery/micro surgery/micro-surgery" in the title and published between 1980 and 2019 were pulled from the WoS database and analyzed by bibliometric methods. The codes for repeatability were as follows: Title: ("micro-surgery”) OR Title: ("micro surgery") OR Title: (microsurgery) and Document Types: (Article) Timespan = 1980-2019. Indexes = SCI-Expanded, SSCI, A \& HCI, CPCI-S, CPCI-SSH, BKCI-S, BKCI-SSH, ESCI). Bibliometric network visualizations were performed using the VOSviewer (Version 1.6.15; Centre for Science and Technology Studies, The Netherlands) package program [11].

Statistical analyses were performed using the Statistical Package for the Social Sciences (SPSS) (Version 22.0, IBM Corp., Armonk, NY) package programming. The normality of data distribution was tested using the Shapiro-Wilk test. The correlation between the number of articles produced by countries and gross domestic product (GDP) (data obtained from the World Bank Group website) [12] and human development index (HDI) (data from the United Nations Development Program Human Development Report 2019) [13] was determined using Spearman's correlation coefficient in accordance with the data distribution. Linear regression analysis was used to estimate the number of articles to be published in the future. A p-value of $<0.05$ was considered significant.

\section{Results}

As a result of the literature review, 3,537 publications were found. A total of 2,063 (58.32\%) of these publications were articles, 441 (12.46\%) were proceedings papers, 430 (12.15\%) were meeting abstracts, 315 (8.90\%) were editorial materials, $186(5.25 \%)$ were letters, and $151(4.26 \%)$ were reviews. The rest were other types of publications: note (46), book chapter (31), correction (12), discussion (8), news item (8), book review (7), biographical item (4), reprint (4), book (3), and correction addition (1). In our study, 2,063 articles were analyzed bibliometrically in the article category. A total of 1,759 (85.2\%) of the articles were published in English, and the rest were published in other languages (German: 139, French: 95, Russian: 37, Spanish: 14, Japanese: 6, Italian: 3, Korean: 3, Czech: 2, Portuguese: 2, Dutch: 1, Greek: 1, and Turkish: 1). A total of 2,063 articles had 37,577 citations (without self-citations: 33,493), the average number of citations was 18.21 , and the h-index was 86 .

\section{Research areas}

More than half of the published articles related to microsurgery were in the field of surgery $(1075 ; 52.1 \%)$. Most of the articles published were in the areas of otorhinolaryngology (254), clinical neurology (221), gastroenterology hepatology (147), medicine general internal (87), obstetrics-gynecology (84), ophthalmology (74), dentistry oral surgery medicine (69), medicine research experimental (67), oncology (59), radiology nuclear medicine medical imaging (57), neurosciences (43), urology nephrology (43), orthopedics (42), and optics (35). Some of the articles were labeled in more than one field.

\section{Development of publications}

The distribution of articles by year is presented in Figure 1. The number of publications for the next five years predicted by regression analysis is also shown in Figure 1 with $95 \%$ confidence intervals. The estimated number of publications was 124 (102-145) for 2020 and 130 (99-161) for 2024. 


\section{Cureus}

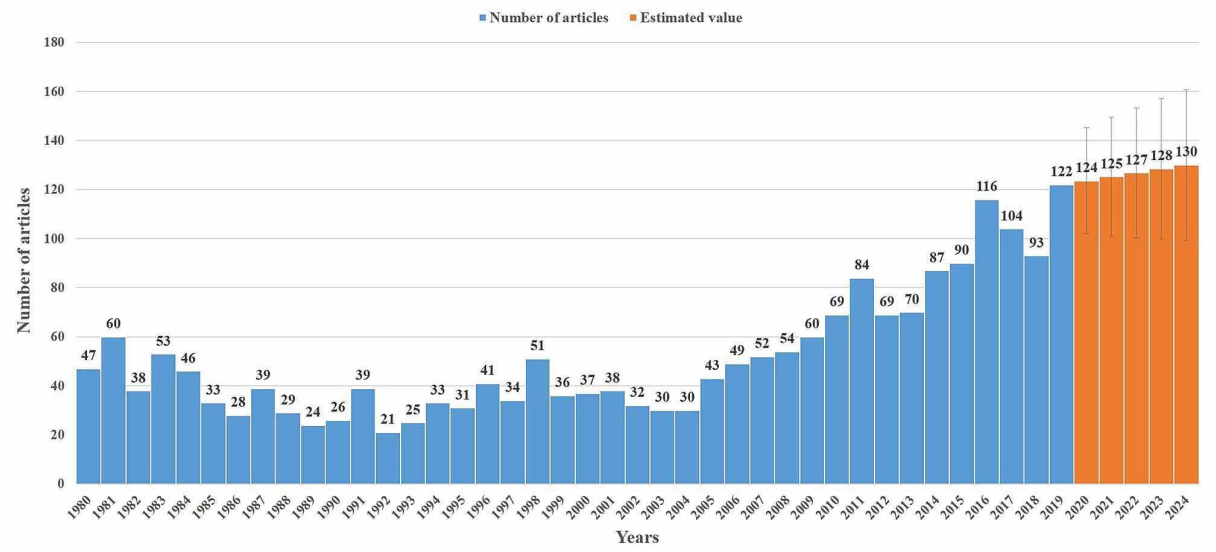

\section{FIGURE 1: Distribution of the number of articles on microsurgery by}

year

Footnote: The orange color shows an estimate of the number of articles to be published in the coming years.

\section{Trend topics}

A total of 2,628 different keywords were used in 2,063 articles. Approximately 76 keywords used in at least eight different articles from these keywords are listed in Table 1 . The network visualization map obtained according to the citation analysis of the articles containing the keywords is shown in Figure 2. 


\section{Cureus}

\begin{tabular}{|c|c|c|c|c|c|c|c|}
\hline Keyword & 0 & Keyword & 0 & Keyword & 0 & Keyword & 0 \\
\hline microsurgery & 311 & laser microsurgery & 19 & aneurysm & 13 & glottic carcinoma & 9 \\
\hline $\begin{array}{l}\text { transanal endoscopic } \\
\text { microsurgery }\end{array}$ & 208 & glottic cancer & 18 & carcinoma & 13 & glottis & 9 \\
\hline rectal cancer & 82 & $\begin{array}{l}\text { stereotactic } \\
\text { radiosurgery }\end{array}$ & 18 & early glottic cancer & 13 & head and neck cancer & 9 \\
\hline transoral laser microsurgery & 74 & cancer & 17 & organ preservation & 13 & meningioma & 9 \\
\hline local excision & 47 & free flap & 17 & rectal neoplasms & 13 & reconstruction & 9 \\
\hline tem(s) & 47 & $\begin{array}{l}\text { squamous cell } \\
\text { carcinoma }\end{array}$ & 17 & education & 12 & simulation & 9 \\
\hline vestibular schwannoma & 39 & training & 17 & neurosurgery & 12 & clinical outcome & 8 \\
\hline surgery & 34 & co2 laser & 16 & rectum & 12 & clipping & 8 \\
\hline endoscopy & 30 & laryngeal cancer & 16 & transanal & 12 & endoscope & 8 \\
\hline quality of life & 29 & outcome & 16 & transsphenoidal surgery & 12 & functional outcome & 8 \\
\hline rectal adenoma & 27 & complications & 15 & rectal carcinoma & 11 & hearing preservation & 8 \\
\hline endodontic microsurgery & 26 & early rectal cancer & 15 & survival & 11 & laparoscopy & 8 \\
\hline minimally invasive surgery & 26 & endoscopic surgery & 15 & anastomosis & 10 & local control & 8 \\
\hline larynx & 25 & laser & 15 & $\begin{array}{l}\text { arteriovenous } \\
\text { malformation }\end{array}$ & 10 & minimally invasive & 8 \\
\hline acoustic neuroma & 24 & radiotherapy & 15 & facial nerve & 10 & pituitary adenoma & 8 \\
\hline rectal tumor(s) & 23 & adenoma & 14 & laryngeal carcinoma & 10 & radiation therapy & 8 \\
\hline radiosurgery & 22 & gamma knife & 14 & prognostic factors & 10 & rectal polyp & 8 \\
\hline recurrence & 20 & laser surgery & 14 & reconstructive surgery & 10 & $\begin{array}{l}\text { total mesorectal } \\
\text { excision }\end{array}$ & 8 \\
\hline carbon dioxide laser & 19 & local recurrence & 14 & transanal excision & 10 & voice & 8 \\
\hline
\end{tabular}

\section{TABLE 1: The first 76 trend keywords on microsurgery}

The first 76 trend keywords on microsurgery

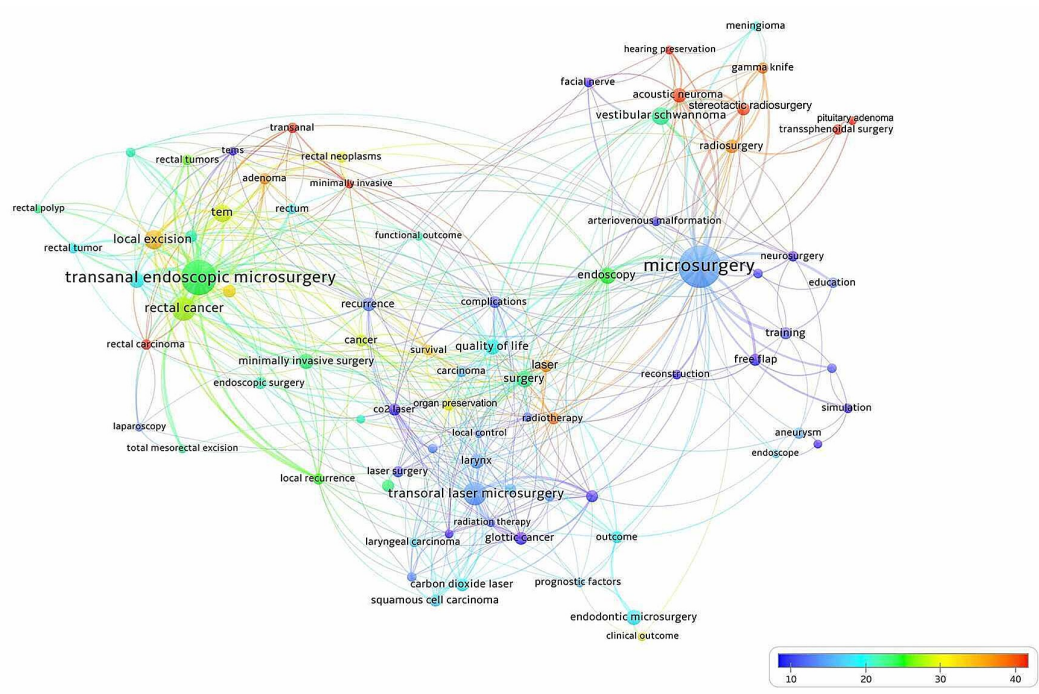




\section{Cureus}

FIGURE 2: Network visualization map for citation analysis of keywords on microsurgery

Footnote: The number of citations taken by keyword increases from blue to red (blue-green-yellow-red). The size of the circles indicates that the keyword is used frequently. The thickness of the lines indicates the strength of the relationship.

\section{Active authors}

Authors who published the most articles on microsurgery were Steiner W (28), De Graaf EJR (24), Campisi C (20), Boccardo F (18), Morino M (17), Arezzo A (15), Allaix ME (14), Doornebosch PG (14), Hinni ML (14), and Lezoche $\mathrm{E}(14)$.

\section{Active organization}

The 16 organizations and organizations-enhanced that published the most articles on microsurgery are presented in Table 2 .

Organizations
University Gottingen
University Genoa
Mayo Clinic
ljsselland Hospital
Harvard University
Johns Hopkins University
University Penn
Leiden University
Stanford University
University Calif Irvine
University Roma La Sapienza
University Turin

\begin{tabular}{|c|c|}
\hline RC & Organizations-Enhanced \\
\hline 34 & Assistance Publique Hopitaux Paris (APHP) \\
\hline 30 & University of California System \\
\hline 24 & University of Gottingen \\
\hline 22 & Harvard University \\
\hline 21 & Mayo Clinic \\
\hline 21 & University of Genoa \\
\hline 21 & University of Texas System \\
\hline 17 & Johns Hopkins University \\
\hline 17 & University of Pennsylvania \\
\hline 17 & ljsselland Hospital \\
\hline 16 & Sapienza University Rome \\
\hline 16 & University of Munich \\
\hline 16 & University of London \\
\hline 14 & Erasmus University Rotterdam \\
\hline 14 & Pennsylvania Commonwealth System of Higher Education (PCSHE) \\
\hline 14 & University of Erlangen Nuremberg \\
\hline
\end{tabular}

TABLE 2: Active organization and organizations-enhanced on microsurgery

\section{Active journals}

A total of 636 journals with 2,063 articles were published. Among these journals, 74 published at least six articles on this subject. The first 74 journals that produced the most publications are presented in Table 3. The table lists the total number of citations and the average number of citations per article.

\begin{tabular}{|l|l|l|l|l|l|l|l|l|l|}
\hline Journals & RC & C & AC & Journals & RC & AC \\
\hline Journal of Reconstructive Microsurgery & 84 & 330 & 3.9 & Frontiers in Oncology & 10 & 30 & 3.0 \\
\hline Microsurgery & 78 & 1392 & 17.8 & Helvetica Chirurgica Acta & 10 & 2 \\
\hline
\end{tabular}




\section{Cureus}

\begin{tabular}{|c|c|c|c|c|c|c|c|}
\hline $\begin{array}{l}\text { Surgical Endoscopy and Other Interventional } \\
\text { Techniques }\end{array}$ & 57 & 2107 & 37.0 & Otology \& Neurotology & 9 & 73 & 8.1 \\
\hline Plastic and Reconstructive Surgery & 43 & 1281 & 29.8 & $\begin{array}{l}\text { Klinische Monatsblatter Fur } \\
\text { Augenheilkunde }\end{array}$ & 9 & 29 & 3.2 \\
\hline Neurosurgery & 35 & 1884 & 53.8 & International Surgery & 9 & 26 & 2.9 \\
\hline Laryngoscope & 34 & 965 & 28.4 & American Journal of Surgery & 8 & 365 & 45.6 \\
\hline Journal of Endodontics & 34 & 880 & 25.9 & $\begin{array}{l}\text { Journal of Otolaryngology-Head \& Neck } \\
\text { Surgery }\end{array}$ & 8 & 107 & 13.4 \\
\hline Colorectal Disease & 34 & 802 & 23.6 & Journal of Hand Surgery-American Volume & 8 & 105 & 13.1 \\
\hline $\begin{array}{l}\text { Head and Neck-Journal for the Sciences and } \\
\text { Specialties of the Head and Neck }\end{array}$ & 34 & 799 & 23.5 & Clinical Otolaryngology & 8 & 93 & 11.6 \\
\hline European Archives of Oto-Rhino-Laryngology & 30 & 423 & 14.1 & $\begin{array}{l}\text { Surgical Laparoscopy Endoscopy \& } \\
\text { Percutaneous Techniques }\end{array}$ & 8 & 66 & 8.3 \\
\hline Annals of Plastic Surgery & 30 & 273 & 9.1 & $\begin{array}{l}\text { International Journal of Medical Robotics } \\
\text { and Computer Assisted Surgery }\end{array}$ & 8 & 55 & 6.9 \\
\hline Acta Neurochirurgica & 27 & 776 & 28.7 & Acta Oto-Laryngologica & 8 & 49 & 6.1 \\
\hline Journal of Neurosurgery & 26 & 1909 & 73.4 & Therapeutische Umschau & 8 & 2 & 0.3 \\
\hline Diseases of The Colon \& Rectum & 25 & 1682 & 67.3 & Surgical Neurology & 7 & 417 & 59.6 \\
\hline Handchirurgie Mikrochirurgie Plastische Chirurgie & 19 & 78 & 4.1 & $\begin{array}{l}\text { Surgical Endoscopy-Ultrasound and } \\
\text { Interventional Techniques }\end{array}$ & 7 & 319 & 45.6 \\
\hline International Journal of Colorectal Disease & 16 & 413 & 25.8 & Journal of Gastrointestinal Surgery & 7 & 155 & 22.1 \\
\hline Otolaryngology-Head and Neck Surgery & 16 & 346 & 21.6 & Journal of Oral and Maxillofacial Surgery & 7 & 150 & 21.4 \\
\hline Clinics in Plastic Surgery & 16 & 159 & 9.9 & $\begin{array}{l}\text { International Journal of Computer Assisted } \\
\text { Radiology and Surgery }\end{array}$ & 7 & 110 & 15.7 \\
\hline HNO & 16 & 97 & 6.1 & Journal of Biomedical Optics & 7 & 91 & 13.0 \\
\hline Vestnik Oftalmologii & 15 & 12 & 0.8 & Lasers in Surgery and Medicine & 7 & 84 & 12.0 \\
\hline British Journal of Surgery & 14 & 854 & 61.0 & Chirurg & 7 & 79 & 11.3 \\
\hline World Neurosurgery & 14 & 55 & 3.9 & Lymphology & 7 & 62 & 8.9 \\
\hline Archives of Gynecology and Obstetrics & 14 & 38 & 2.7 & British Journal of Plastic Surgery & 7 & 42 & 6.0 \\
\hline Fertility and Sterility & 13 & 457 & 35.2 & Annales De Chirurgie Plastique Esthetique & 7 & 16 & 2.3 \\
\hline Techniques in Coloproctology & 13 & 91 & 7.0 & Khirurgiya & 7 & 1 & 0.1 \\
\hline Minimally Invasive Therapy \& Allied Technologies & 13 & 89 & 6.8 & Vestnik Khirurgii İmeni II Grekova & 7 & 0 & 0.0 \\
\hline Annals of Otology Rhinology and Laryngology & 12 & 299 & 24.9 & World Journal of Surgery & 6 & 161 & 26.8 \\
\hline $\begin{array}{l}\text { Journal of Laparoendoscopic \& Advanced Surgical } \\
\text { Techniques }\end{array}$ & 12 & 56 & 4.7 & Acta Orthopaedica Scandinavica & 6 & 115 & 19.2 \\
\hline Plastic and Reconstructive Surgery-Global Open & 12 & 23 & 1.9 & Neurosurgical Focus & 6 & 90 & 15.0 \\
\hline Neurochirurgie & 11 & 86 & 7.8 & Hepato-Gastroenterology & 6 & 65 & 10.8 \\
\hline Laryngo-Rhino-Otologie & 11 & 51 & 4.6 & Chinese Medical Journal & 6 & 51 & 8.5 \\
\hline Journal Francais D Ophtalmologie & 11 & 19 & 1.7 & Plos One & 6 & 45 & 7.5 \\
\hline Biomedical Optics Express & 10 & 219 & 21.9 & Medicine & 6 & 16 & 2.7 \\
\hline Journal of Voice & 10 & 177 & 17.7 & Neurological Surgery & 6 & 13 & 2.2 \\
\hline $\begin{array}{l}\text { Journal of Plastic Reconstructive and Aesthetic } \\
\text { Surgery }\end{array}$ & 10 & 157 & 15.7 & Acta Chirurgica Belgica & 6 & 9 & 1.5 \\
\hline
\end{tabular}

Australian and New Zealand Journal of 


\section{Cureus}

Minimally Invasive Neurosurgery

10

$121 \quad 12.1$ Surgery

\section{TABLE 3: Active journals on microsurgery}

\section{Active countries}

A total of 2,063 articles were published, with a total of 85 country addresses. Active countries producing more than 20 publications are the United States (US) (504), Germany (286), Germany (52), Italy (154), United Kingdom (UK) (145), France (139), China (113), Japan (81), Switzerland (69), Canada (65), Spain (60), Netherlands (58), South Korea (52), Belgium (43), Australia (41), Austria (37), Taiwan (34), Brazil (31), Turkey (28), Israel (24), Russia (21), and Union of Soviet Socialist Republics (37). The network map showing at least five publications from these countries and showing international cooperation among the 34 countries are illustrated in Figure 3.

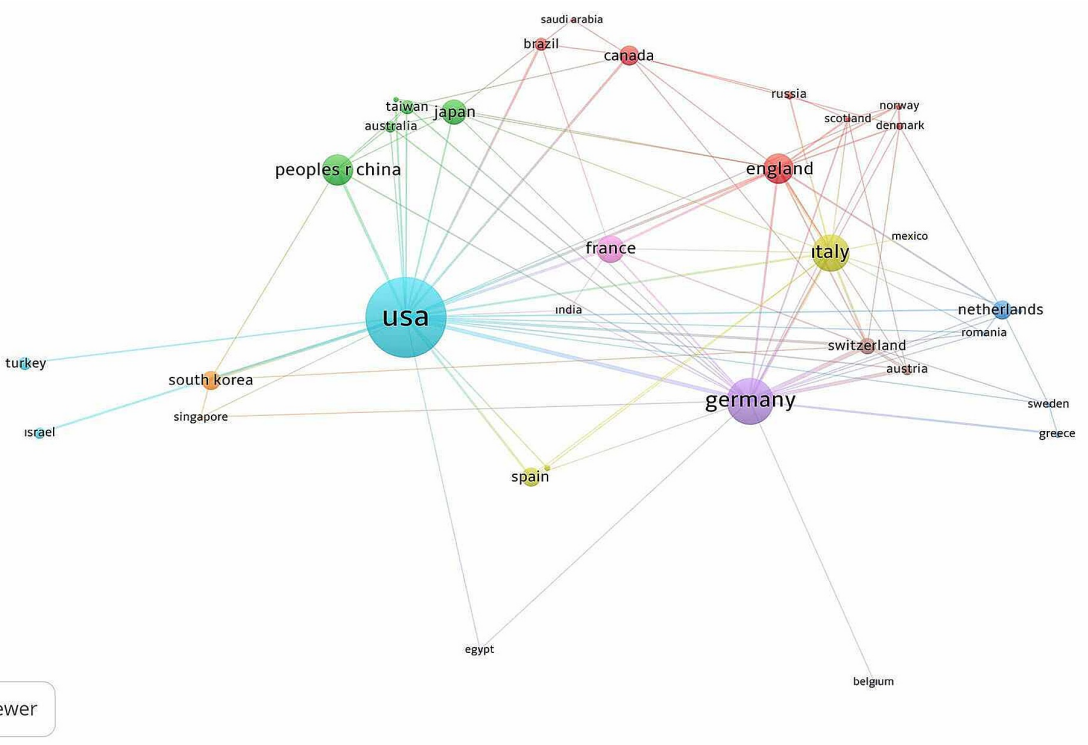

\section{FIGURE 3: Network visualization map for the international collaboration of worldwide countries on microsurgery}

Footnote: The size of the circle shows the large number of publications, the colors indicate the cluster of collaboration, and the thickness of the lines indicates the strength of the collaboration.

\section{Correlation analysis}

A statistically significant correlation was found between the number of articles published by countries on microsurgery and the GDP and HDI sizes of countries $(r=0.758, p<0.001, r=0.659, p<0.001)$. Scatter plots of correlations are presented in Figure 4.
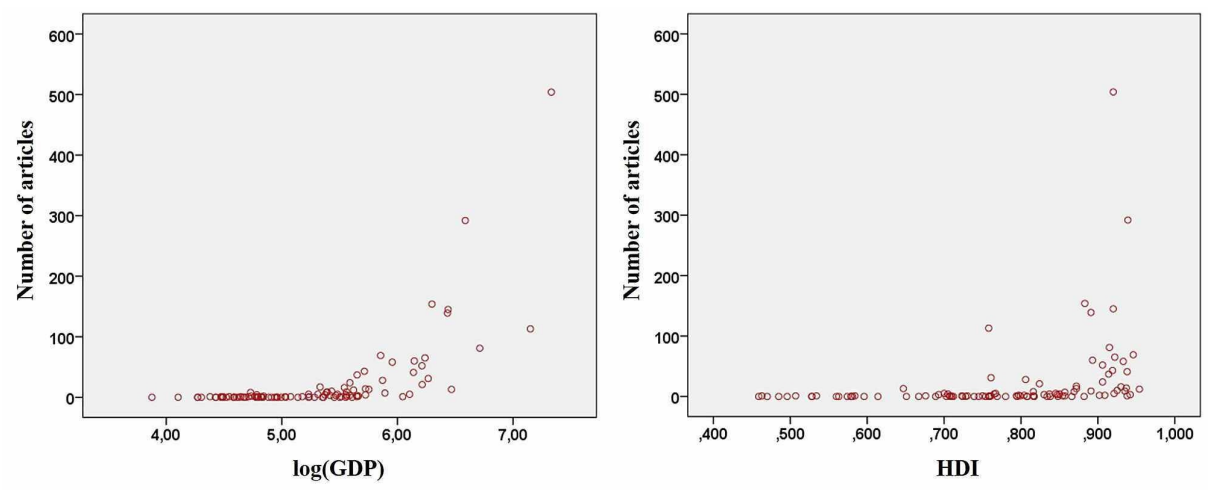


\section{Co-citation analysis}

In the references section of 2,063 articles, 29,387 publications were referred. Among these were eight publications that received more than 50 citations. These most cited publications were Buess (1984) (number of citations: C; 114), Winde (1996) (C: 86), Middleton (2005) (C: 68), Heintz (1998) (C: 60), Moore (2008) (C: 56), Lee (2003) (C: 53), Mellgren (2000) (C: 52), and Buess (1992) (C: 51) [14-21].

\section{Citation analysis}

When the analyzed articles were evaluated according to the total number of citations and the average number of citations per year, the most cited study was Anderson et al.'s study titled "Selective photothermolysis - precise microsurgery by selective absorption of pulsed radiation” published in Science in 1983 [22]. The remaining most cited articles were performed by Sylla et al. [23], Haughey et al. [24], Hutson et al. [25], and Bach et al. [26], respectively. The articles were ranked according to the average number of citations per year, and the first five articles are presented in Table 4 [22-26]. The total citation numbers of the articles are also provided in the table.

\begin{tabular}{|c|c|c|c|c|c|c|}
\hline No & Article & Author & Journal & PY & TC & AC \\
\hline 1 & $\begin{array}{l}\text { Selective photothermolysis - precise microsurgery by } \\
\text { selective absorption of pulsed radiation }\end{array}$ & $\begin{array}{l}\text { Anderson, } \\
\text { RR. et al. } \\
\text { [22] }\end{array}$ & Science & 1983 & 1952 & 51.37 \\
\hline 2 & $\begin{array}{l}\text { Notes transanal rectal cancer resection using transanal } \\
\text { endoscopic microsurgery and laparoscopic assistance }\end{array}$ & $\begin{array}{l}\text { Sylla, P. et } \\
\text { al. [23] }\end{array}$ & $\begin{array}{l}\text { Surgical Endoscopy and Other } \\
\text { Interventional Techniques }\end{array}$ & 2010 & 312 & 28.36 \\
\hline 3 & $\begin{array}{l}\text { Transoral laser microsurgery as primary treatment for } \\
\text { advanced-stage oropharyngeal cancer: a united states } \\
\text { multicenter study }\end{array}$ & $\begin{array}{l}\text { Haughey, } \\
\text { Bruce H. et } \\
\text { al. [24] }\end{array}$ & $\begin{array}{l}\text { Sciences and Specialties of the } \\
\text { Head and Neck }\end{array}$ & 2011 & 209 & 20.9 \\
\hline 4 & $\begin{array}{l}\text { Forces for morphogenesis investigated with laser } \\
\text { microsurgery and quantitative modeling }\end{array}$ & $\begin{array}{l}\text { Hutson, MS. } \\
\text { et al. [25] }\end{array}$ & Science & 2003 & 344 & 19.11 \\
\hline 5 & $\begin{array}{l}\text { A predictive model for local recurrence after transanal } \\
\text { endoscopic microsurgery for rectal cancer }\end{array}$ & $\begin{array}{l}\text { Bach, SP. et } \\
\text { al. [26] }\end{array}$ & British Journal of Surgery & 2009 & 213 & 17.75 \\
\hline
\end{tabular}

TABLE 4: The five most cited manuscripts on microsurgery

\section{Discussion}

According to our comprehensive statistical analysis findings with 2,063 articles, a significant increase was observed in the number of articles on microsurgery especially after 2005. The number of articles published ranged from 21 to 60 per year between 1980 and 2009. The number of articles exceeded 60 in 2010 and reached 122 in 2019 . When the regression analysis results were evaluated, we observed that the number of articles published will continue to increase.

When the results of the keyword analysis were evaluated, the top 10 topics related to microsurgery investigated were transanal endoscopic microsurgery (TEM), rectal cancer/adenoma, transoral laser microsurgery, local excision, vestibular schwannoma, endoscopy, quality of life, endodontic microsurgery, minimally invasive surgery, and larynx. According to the results of cluster analysis, four major primary clusters were formed based on the topics used in similar articles: microsurgery, transanal endoscopic microsurgery/rectal cancer/local excision, transoral laser microsurgery/quality of life, and vestibular schwannoma/acoustic neuroma. The literature on microsurgery developed four main clusters, with a total of eight different clusters.

According to the results of trend analysis to determine the current research topics, issues related to transanal endoscopic microsurgery, rectal carcinoma/tumors, laser microsurgery, endoscopy, transsphenoidal surgery, gamma knife, and pituitary adenoma were initially studied; in the following years, acoustic neuroma, stereotactic radiosurgery, radiotherapy, arteriovenous malformation, local excision, 
minimally invasive, transanal, rectal neoplasms, rectal polyp, laparoscopy, facial nerve, hearing preservation, neurosurgery, anastomosis, vestibular schwannoma, reconstructive surgery, meningioma, aneurysm, clipping, larynx, survival, carcinoma, local recur, carcinoma, carbon dioxide laser, squamous cell carcinoma, early glottic cancer, and organ preservation were studied. In recent years, subjects such as transoral laser microsurgery, quality of life, training, education, free flap, simulation, endodontic microsurgery, recurrence, $\mathrm{CO} 2$ laser, head and neck cancer, outcome, glottis cancer, voice, glottis, and local control have been explored. The keywords used in more cited articles were acoustic neuroma, stereotactic radiosurgery, hearing preservation, transsphenoidal surgery, pituitary adenoma, minimally invasive, transanal, rectal carcinoma, gamma knife, radiosurgery, radiotherapy, laser, adenoma, and local excision.

The most active journals producing more than 30 publications were the Journal of Reconstructive Microsurgery, Microsurgery, Surgical Endoscopy and Other Interventional Techniques, Plastic and Reconstructive Surgery, Neurosurgery, Laryngoscope, Journal of Endodontics, Colorectal Disease, and Head and Neck-Journal for the Sciences and Specialties of the Head and Neck. Researchers who want to publish manuscripts on this subject can consider these journals. When the journals were evaluated according to the number of citations per article, Journal of Neurosurgery, Diseases of the Colon \& Rectum, British Journal of Surgery, Surgical Neurology, Neurosurgery, American Journal of Surgery, Surgical Endoscopy-Ultrasound and Interventional Techniques, Surgical Endoscopy, and Other Interventional Techniques journals came to the fore as the more cited journals. Researchers who want their articles to be cited more can first consider these journals.

When the publication distributions of the world countries were analyzed, we found that developed countries produce the most publications in microsurgery (US, Germany, Italy, UK, France, Japan, Switzerland, Canada, Spain, Netherlands, South Korea, Belgium, Australia, Austria, Taiwan, and Israel) or developing countries with large economies (China, Brazil, Turkey, and Russia). When the relation graph plotted for the correlations was evaluated, countries with HDI 0.88 and above provided remarkable article contributions. Countries with a log (GDP) value of more than 5.6 (about 400,000 GDP) contributed significantly to the attention. Some studies conducted in the literature reported that the economic size or development levels of the countries had a significant effect on academic publication productivity [4-5]. Some cutting points were discussed in our study. When co-authoring cooperation of countries was evaluated, we found that geographical regional neighborhood is an important factor in cooperation.

When the analyzed articles were evaluated according to the total number of citations and the average number of citations per year, the most cited study was Anderson et al.'s study titled "Selective photothermolysis - precise microsurgery by selective absorption of pulsed radiation” published in Science in 1983 [22]. The remaining most cited articles were presented in Table 4 [23-26]. Buess (1984), Winde (1996), Middleton (2005), Heintz (1998), Moore (2008), Lee (2003), Mellgren (2000), and Buess (1992) were cited in all the articles analyzed according to the co-citation analysis findings [14-21]. Researchers interested in this subject should read these studies, which are determined primarily by attribution and co-citation analysis.

In our study, comprehensive bibliometric analyses, such as keyword analysis, citation analysis for articles and journals, international collaborations, and correlation analyses, were performed for the first time in this study. Our study is the most comprehensive research in the literature in which the most articles are analyzed on this subject.

This study has some limitations. It only reviewed the articles published in the WoS database. The PubMed and Scopus databases were not included for analysis. In the bibliometric studies where many articles were analyzed, if multiple databases are used, the same articles (there maybe thousands) in different databases can be included in the analysis twice. This will negatively affect the reliability of the results.

\section{Conclusions}

As a result of our study on microsurgery, which has an increase in the number of articles every day in the literature, summary information of 2,063 articles published between 1980 and 2019 was presented. The most active publishing countries were the US, Germany, and Italy. There was a significant correlation between article numbers and countries' GDP and HDI sizes. The top three journals to publish articles were the Journal of Reconstructive Microsurgery, Microsurgery, and Surgical Endoscopy and Other Interventional Techniques. The most active institution was University Gottingen.

The researchers will be able to get ideas for new studies on this subject by evaluating the development of the topics studied by year, the trending topics, and the topics that received more citations. Hence, this study will be a useful guide for clinicians and scientists on the global outcomes of studies on microsurgery.

\section{Additional Information \\ Disclosures}

Human subjects: All authors have confirmed that this study did not involve human participants or tissue. Animal subjects: All authors have confirmed that this study did not involve animal subjects or tissue. 
Conflicts of interest: In compliance with the ICMJE uniform disclosure form, all authors declare the following: Payment/services info: All authors have declared that no financial support was received from any organization for the submitted work. Financial relationships: All authors have declared that they have no financial relationships at present or within the previous three years with any organizations that might have an interest in the submitted work. Other relationships: All authors have declared that there are no other relationships or activities that could appear to have influenced the submitted work.

\section{References}

1. Mavrogenis AF, Markatos K, Saranteas T, et al.: The history of microsurgery. Eur J Orthop Surg Traumatol. 2019, 29:247-254. 10.1007/s00590-019-02378-7

2. Tamai S: History of microsurgery-from the beginning until the end of the 1970s . Microsurgery. 1993, 14:613.

3. Tintle SM, Levin LS: The reconstructive microsurgery ladder in orthopaedics . Injury. 2013, 44:376-385. 10.1016/j.injury.2013.01.006

4. Doğan G, Karaca O: A bibliometric analysis of the field of anesthesia during 2009-2018: a bibliometric analysis of anesthesia. Braz J Anesthesiol. 2020, 70:140-152. 10.1016/j.bjane.2020.04.013

5. Kiraz M, Demir E: A bibliometric analysis of publications on spinal cord injury during 1980-2018. World Neurosurg. 2020, 136:504-513. 10.1016/j.wneu.2020.01.064

6. Muslu Ü, Demir E: Development of rhinoplasty: yesterday and today . Med Sci. 2019, 23:294-301.

7. Doğan G: The effect of religious beliefs on the publication productivity of countries in circumcision: a comprehensive bibliometric view. J Relig Health. 2020, 59:1126-1136. 10.1007/s10943-020-00985-x

8. Doğan G, İpek H: The development of necrotizing enterocolitis publications: a holistic evolution of global literature with bibliometric analysis. Eur J Pediatr Surg. 2019, 30:293-303. 10.1055/s-0039-3400514

9. Demir E, Comba A: The evolution of celiac disease publications: a holistic approach with bibliometric analysis. Ir J Med Sci. 2020, 189:267-276. 10.1007/s11845-019-02080-x

10. Demir E, Akmeşe ÖF, Erbay H, Taylan-Özkan A, Mumcuoğlu KY: Bibliometric analysis of publications on house dust mites during 1980-2018. Allergol Immunopathol (Madr). 2020, 48:374-383. 10.1016/j.aller.2020.01.001

11. Van Eck NJ, Waltman L: Software survey: VOSviewer, a computer program for bibliometric mapping . Scientometrics. 2010, 84:523-538. 10.1007/s11192-009-0146-3

12. World Bank. International Comparison Program database. Accessed: May 5, 2020: https://data.worldbank.org/indicator/NY.GDP.MKTP.CD.

13. United Nations Development Programme. Human Development Report . (2019). Accessed: May 5, 2020: http://hdr.undp.org/en/2019-report/download.

14. Buess G, Hutterer F, Theiss J, Bobel M, Isselhard W, Pichlmaier H: A system for a transanal endoscopic rectum operation [Article in German]. Chirurg. 1984, 55:677-680.

15. Winde G, Nottberg H, Keller R, Schmid KW, Bünte H: Surgical cure for early rectal carcinomas (T1). Dis Colon Rectum. 1996, 39:969-976. 10.1007/BF02054683

16. Middleton PF, Sutherland LM, Maddern GJ: Transanal endoscopic microsurgery: a systematic review . Dis Colon Rectum. 2005, 48:270-284.

17. Heintz A, Mörschel M, Junginger T: Comparison of results after transanal endoscopic microsurgery and radical resection for T1 carcinoma of the rectum. Surg Endosc. 1998, 12:1145-1148. 10.1007/s004649900802

18. Moore JS, Cataldo PA, Osler T, Hyman NH: Transanal endoscopic microsurgery is more effective than traditional transanal excision for resection of rectal masses. Dis Colon Rectum. 2008, 51:1026-1031. 10.1007/s10350-008-9337-x

19. Lee $\mathrm{W}$, Lee $\mathrm{D}$, Choi S, Chun H: Transanal endoscopic microsurgery and radical surgery for $\mathrm{T} 1$ and $\mathrm{T} 2$ rectal cancer. Surg Endosc. 2003, 17:1283-1287. 10.1007/s00464-002-8814-X

20. Mellgren A, Sirivongs P, Rothenberger DA, Madoff RD, García-Aguilar J: Is local excision adequate therapy for early rectal cancer?. Dis Colon Rectum. 2000, 43:1064-1071. 10.1007/BF02236551

21. Buess G, Mentges B, Manncke K, Starlinger M, Becker HD: Technique and results of transanal endoscopic microsurgery in early rectal cancer. Am J Surg. 1992, 163:63-70. 10.1016/0002-9610(92)90254-0

22. Anderson RR, Parrish JA: Selective photothermolysis: precise microsurgery by selective absorption of pulsed radiation. Science. 1983, 220:524-527. 10.1126/science.6836297

23. Sylla P, Rattner DW, Delgado S, Lacy AM: NOTES transanal rectal cancer resection using transanal endoscopic microsurgery and laparoscopic assistance. Surg Endosc. 2010, 24:1205-1210. 10.1007/s00464010-0965-6

24. Haughey BH, Hinni ML, Salassa JR, et al.: Transoral laser microsurgery as primary treatment for advancedstage oropharyngeal cancer: a United States multicenter study. Head Neck. 2011, 33:1683-1694.

25. Hutson MS, Tokutake Y, Chang MS, Bloor JW, Venakides S, Kiehart DP, Edwards GS: Forces for morphogenesis investigated with laser microsurgery and quantitative modeling. Science. 2003, 300:145149. 10.1126/science.1079552

26. Bach SP, Hill J, Monson JRT, et al.: A predictive model for local recurrence after transanal endoscopic microsurgery for rectal cancer. Br J Surg. 2009, 96:280-290. 